\title{
TRADITIONAL HEALING PRACTICE IN RAJBANSHI AND SATAR COMMUNITY OF JHAPA, NEPAL
}

Raut $\mathrm{B}^{1^{*}}$, Khanal DP ${ }^{1}$, Kharel $\mathrm{A}^{1}$

${ }^{1}$ Manmohan Memorial Institute of Health Sciences, Solteemode Kathmandu

*Corresponding author:

Bechan Raut, Associate Professor, Department of Pharmacy, Manmohan Memorial Institute of Health Sciences, Solteemode Kathmandu, Email: rautbechan@yahoo.com

\section{ABSTRACT}

Background: Jhapa is the easternmost district of Nepal and lies in Terai plains. Traditional healing system in Nepal has strong cultural and religious background. It exists in different ways such as ethnic or tribal group, ritual or ceremonial practices. In Nepal, traditional healers believe that the disease causing factors are not only the germ theory related but also the spiritual belief. As the census of 2011, there are eight densely populated indigenous ethnic communities including Satar and Rajbansi in Jhapa. The traditional healers of these communities with their indigenous knowledge serve the local people since time immemorial. The main objective of this research work was to find the traditional healing practice in Rajbanshi and Satar community of Jhapa, district, Nepal.

Methods: The areas were visited from June 2017 to September 2017. A cross sectional study was performed to collect the information through semi structured questionnaires and face to face interviews with the traditional healers of Satar and Rajbanshi community. All together 20 locally reputed traditional healers, 10 from each community were selected.

Results: Spiritual based five healing techniques and/or approaches, Phukphak, Tantrik Puja, Bali, Jantar-mantar and kul bigreko, used by traditional healers were explored. Moreover, 41 plant species belonged to 29 families were found to be used for the treatment of 22 common illnesses. 6 different dosage forms were used to prepare 28 traditional formulations.

Conclusion: Spiritual based five healing techniques and/or approaches were used by traditional healers on this locality. We also identified different medicinal plant species that were used in different traditional formulation used by such healers.

Keywords: Traditional healers, Satar and Rajbanshi, Indigenous technique, Crude drugs, Human ailments

\section{INTRODUCTION}

Traditional healing system in Nepal has strong cultural and religious background. It exists in different ways such as ethnic or tribal group, ritual or ceremonial practices. In Nepal, traditional healers believe that the disease causing factors are not only the germ theory related but also the spiritual belief. The concept of spiritual belief trust that the sickness has come from external source through the external agent and solution to the problem must be found in cosmic system ${ }^{1}$ 
Prem K. Khatry ${ }^{1}$ found that the methods adopted by a Nepali healer were diagnostic orders; soliciting the help of deities possessed by the healer. a. Primary level Phukphak - jharne blowing of breath into the body; puja - worship of deities; bali - small sacrifice of animals; jantar mantar - wearing healing amulets. These are the miscellaneous methods depending on local cultural traditions. b. Secondary level Chinta basne - use the tantric cosmos for special possession effect. Lastly there are the referral cases which include the cases beyond the capacity of the healer.

The faith healing system or shamanistic system treats the diseases by prayer and exercise of faith in god and they are not included in the official health care system. In Nepal faith healers are Dhami- Jhakri, Pandit-Lama-Pujari -Gubhaju, Jyotshi and Gosai Achhat. One of them is ban jhakari belonged to the group of Dhami-Jhakari and exercise evil sprits from the bodies of sick people. A kirati shaman is called mangpa and in the eastern part of the country, they are called bijuwa. They are commonly called as phukne manchhe in Nepali language. Pandit-Lama-Pujari Gubhaju are the priests of different ethnic and religious groups in Nepal. Pandit and Pujari are the Hindu priests. Gubhaju are the priest of Buddhist Newar. Lamas are the priest at Buddhist monasteries. They all diagnose and cure illness through prayers and rituals. Jyotshi are the astrologers. They read the horoscope, palm and fore head of the patients. Gosai acchat includes grains of rice and flowers with blessing words which are provided to the patients by a shaking and shivering person ${ }^{2}$.

The indigenous knowledge for the treatment of ailments has been transmitting from generation to generation in the form of inherited culture. These practices have been handed down verbally and only few of the information were documented in books and in many other religious scripts. The knowledge of the healers is at the edge of extinction due to lack of proper record and socio cultural transformation ${ }^{3}$.

In Nepal more than 61 indigenous ethnic groups are dispersed throughout the country. Jhapa is the easternmost district of Nepal and lies in Terai plains. It is situated on $26^{0} 29$ 'north latitude and $87^{\circ} 51^{\prime}$ eastern longitude and with altitude ranging from $58 \mathrm{~m}$ to $500 \mathrm{~m}$ above the sea level. Rajbanshi and Satar are the major ethnic group of Jhapa, eastern part of Nepal ${ }^{4}$. They are inhabited in Anarmuni, Chandragadi, Garamuni, Rajgadh, Dagibari and Charpane. Rajbanshi and Satar have their own native languages known as Rajbanshi and Santhali respectively. They are rich in folklore and folk tradition and have rich culture and sound traditional knowledge. They use various plants in their culture and traditions and also to treat the various human illness from generation to generation.

Documentation of their indigenous knowledge through the ethnobiological approach may be significant to lead the discovery of drugs or to contribute for the economic development of local as well as nation ${ }^{5}$. In Nepal, a number of ethnobiological studies have been conducted ${ }^{6,7,8,9,10,11 \text {, }}$ ${ }^{12,13}$ but many parts of the country remain unexplored. 


\section{MATERIALS AND METHODS}

The areas were visited from June 2017 to September 2017. A cross sectional study was performed to collect the information through semi structured questionnaires and face to face interviews with traditional healers of Rajbanshi and Satar community. All together 20 locally reputed traditional healers, 10 from each community were selected. The information on the traditional healing system and use of crude drugs were cross checked through the repeated queries in different sites to get the accurate and valid information.

The data were considered valid if at least 3-5 healers had similar positive reply about the healing system and the use of crude drugs. The samples were collected and purchased on the site. They were identified with the help of standard literatures such as Trease and Evans ${ }^{15}$, Wallis ${ }^{16}$, Rajbhandari ${ }^{17}$ and Bulletin of Medicinal Plant of Nepal ${ }^{18}$. The collected specimens were deposited in the Pharmacognosy Laboratory of Manmohan Memorial Institute of Health Sciences, Soalteemode, Kathmamdu, Nepal.

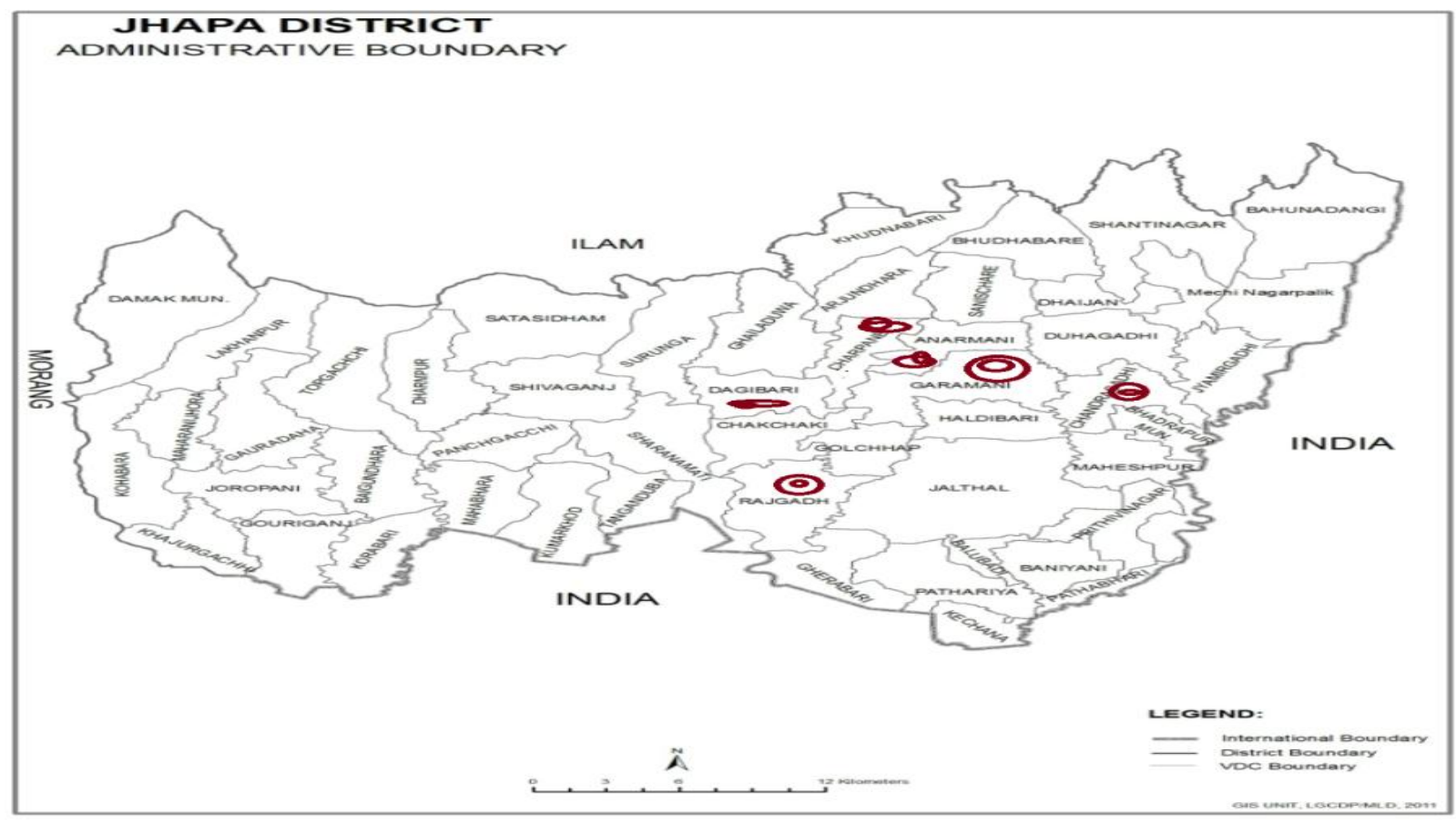

Figure 1: Location of study area in Jhapa district. 


\section{RESULTS AND DISCUSSION}

Traditional healers in Rajbanshi and Satar community were aged between 50 to 70 years. In Rajbanshi and Satar community, spiritual based five healing techniques used by traditional healers were Phukphak, Tantrik Puja, Bali, Jantar-Mantar and Kul Bigreko.

(a) Phukphak- It included chanting, blowing and touching the body with the following mentioned items obtained from plants, animals and minerals. 7 items from plants, 1 from animal and 1 from mineral were used for this purpose. This processs was similar which was mentioned by Prem K Khattry.

Table 1: Traditional Healers' Items for Phukphak

\begin{tabular}{|c|c|c|c|c|}
\hline Items & Local Name & Scientific Name & Parts Used & Uses \\
\hline \multirow[t]{7}{*}{ Plants } & Chamal & Oryza sativa & Seed & \multirow{9}{*}{$\begin{array}{l}\text { All these items } \\
\text { were used while } \\
\text { doing phukphak } \\
\text { of different } \\
\text { disease like bayu, } \\
\text { grahadasa, masan } \\
\text { lageko, sato jane } \\
\text { and others } \\
\text { common disease. }\end{array}$} \\
\hline & Amriso & Thysanolena latifolia & Stem and flower & \\
\hline & Tulsi & Ocimum sanctum & Leaves and flower & \\
\hline & Luang & Eugenia caryophyllus & Flowering tops & \\
\hline & Besar & Curcuma longa & Rhizomes & \\
\hline & Parijat & Nyctanthes arbostristis & Flower & \\
\hline & Mass ko dal & Phaseolous aureus & Seed & \\
\hline Animals & $\begin{array}{l}\text { Kukhura ko } \\
\text { pwakh }\end{array}$ & $\begin{array}{l}\text { Gallus gallus } \\
\text { domesticus }\end{array}$ & Feathers & \\
\hline Mineral & $\begin{array}{l}\text { Falam } \\
\text { tukra }\end{array}$ & Iron & Piece of iron & \\
\hline
\end{tabular}

(b) Tantrik Puja - This puja was done mainly for God Shiva and Goddess Kalimata at midnight. This puja was performed by enchanting mantra upto 12500 times using below items. These included the following item

Table 2: Traditional Healer's Items for Tantrik Puja

Lord Shiva Puja

\begin{tabular}{lllll}
\hline Items & $\begin{array}{l}\text { Local } \\
\text { Name }\end{array}$ & Scientific Name & Parts used & Method of Puja \\
Plants & $\begin{array}{l}\text { Kalo } \\
\text { chamal }\end{array}$ & Oryza sativa & Seed & $\begin{array}{l}\text { This puja was performed by } \\
\text { enchanting mantra up to 12500 }\end{array}$
\end{tabular}




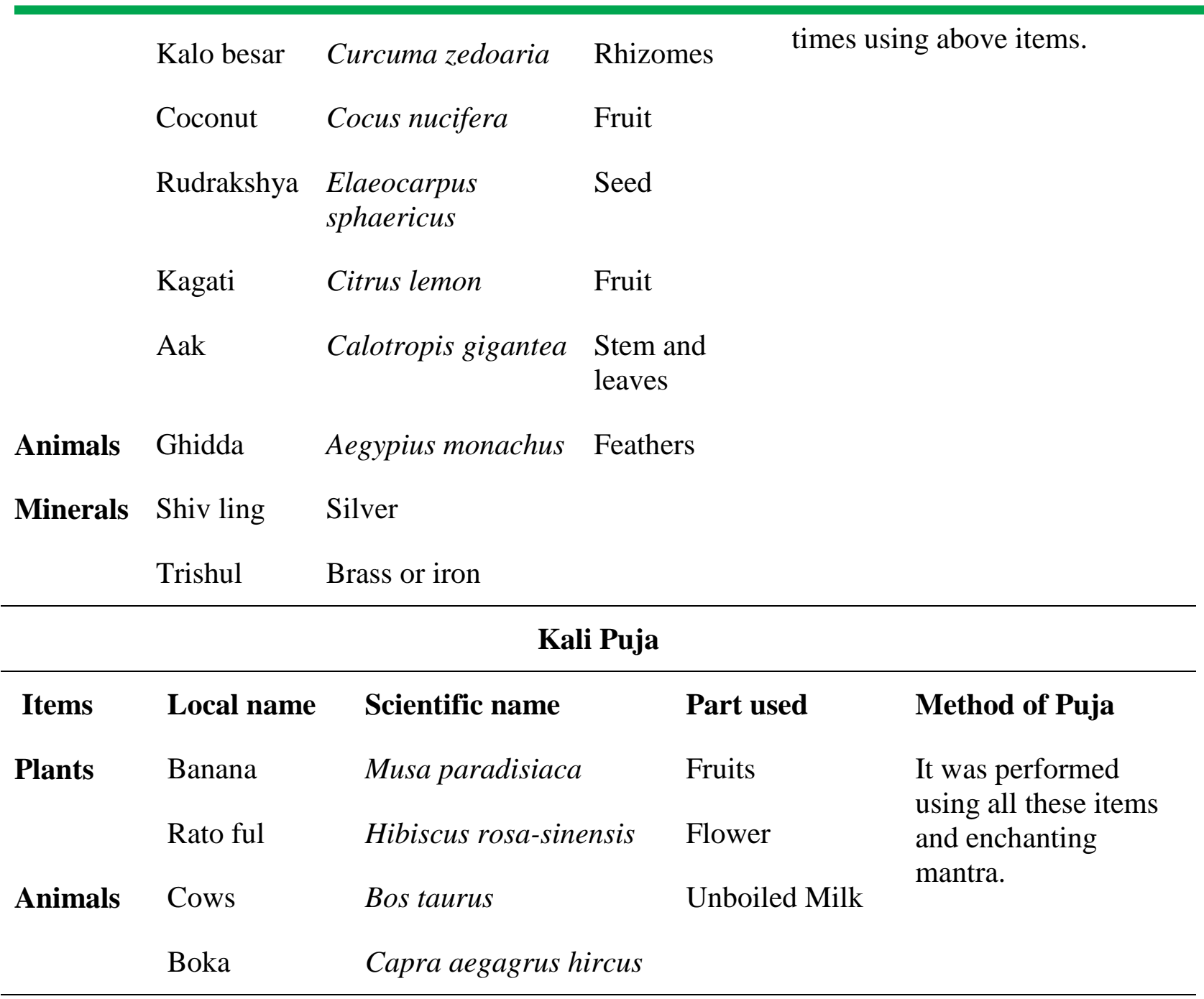

(c) Bali- It was done by sacrificing animals Kalo boka (Black Capraaegagrus hircus), as well as Kuvindo (Benincasa hispida), Ghiroula (Luffa cylindrica)

(d) Jantar-Mantar - They were also known as buti in their locality. They suggested to wear on neck, hands fingers and waist in form of amulet and charm made from silver, brass, copper, iron as well as black clothes. The ingredients of buti were rhizomes of Bhutkesh (Nardostachys jatamansi), roots of Lajjawati jhar (Mimosa pudica), fur of kasturi mrig (Moschus chrysogaster) and piece of leather shoes.

(e) Kul bigreko - This was treated by traditional healers (Rajbanshi guru) and they worshiped of Hanuman (ardent devotee of Lord Ram and one of central characters in Ramayana) and Narsing (known as God protector). The main items for kul puja are kera (Musa paradisiaca), milk of cow (Bos taurus), sugar, curd, bitten rice, Ganga jal (water from famous holy river, Ganga).

Altogether 41 plant species belonged to 29 families which were found to be used for the treatment of 22 common illnesses and 5 spiritual therapies. 6 different dosage forms were used to prepare 28 traditional formulations. The mostly used parts of plants were fruits (12) followed by 


\section{Original Article}

leaves (7) and equal number of flowers, aerial parts, rhizomes i.e. 4. Similarly, roots, barks, (leaves + flower), and seeds shared uniformly i.e. 2. Only one species of flowering bud was found among them. The mostly used dosage form was powder $(25 \%)$, followed by paste $(22 \%)$, juice $(21 \%)$, decoction (14\%), latex $(2 \%)$ and oil $(2 \%)$. The route of administration for oral was highest (72\%) followed by topical (24\%) and ophthalmic (4\%).

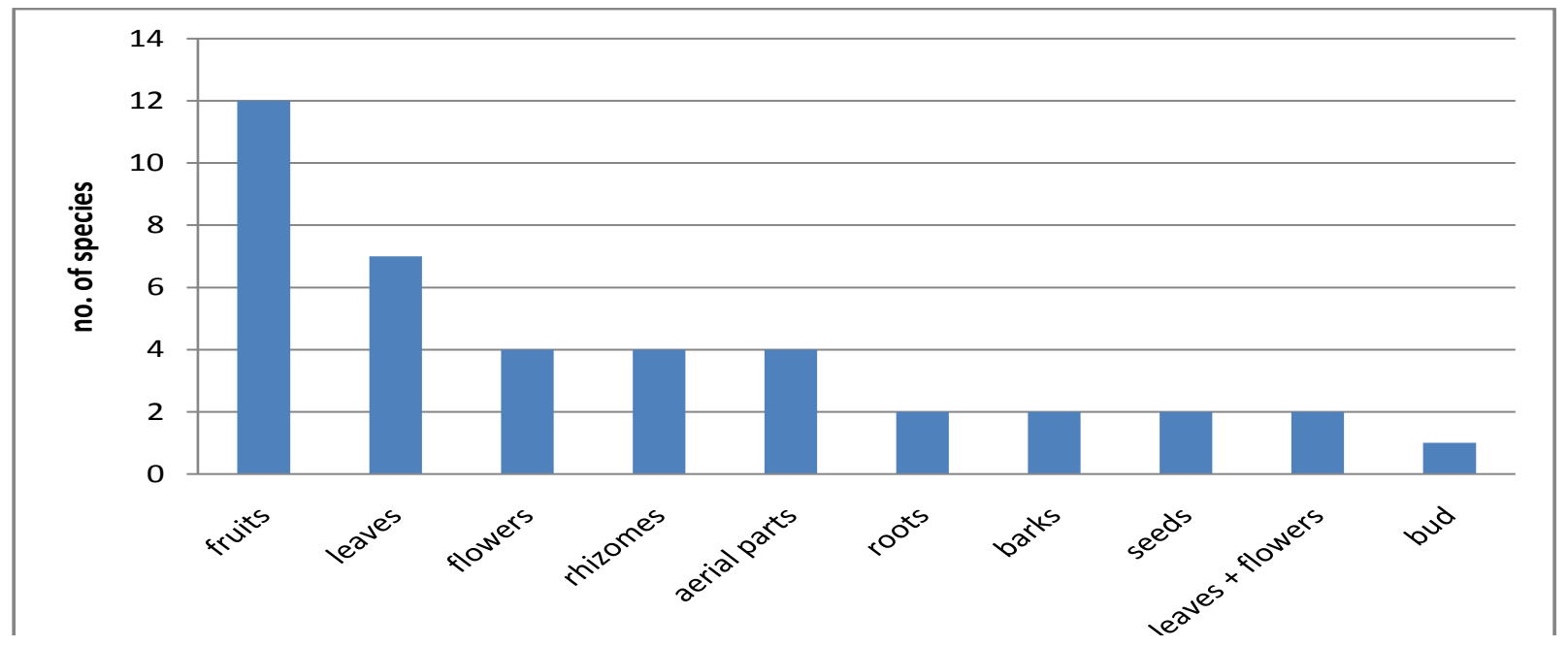

Fig 2: Distribution of crude drugs based on their parts used

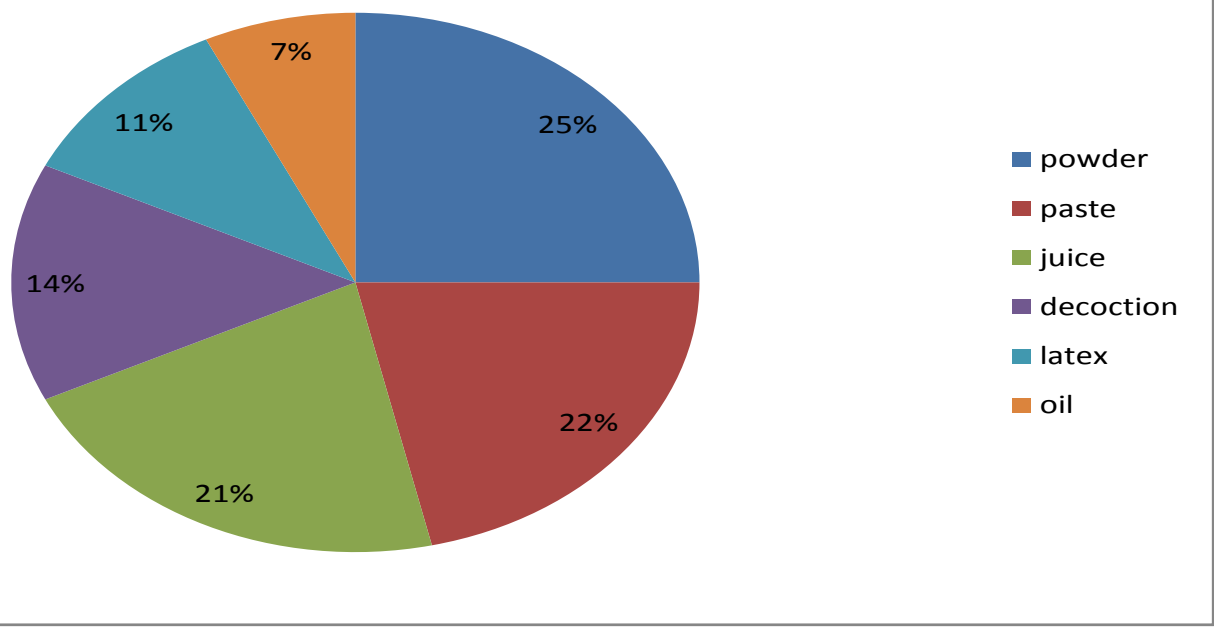

Figure 3: Distribution of crude drugs based on their different dosage form 


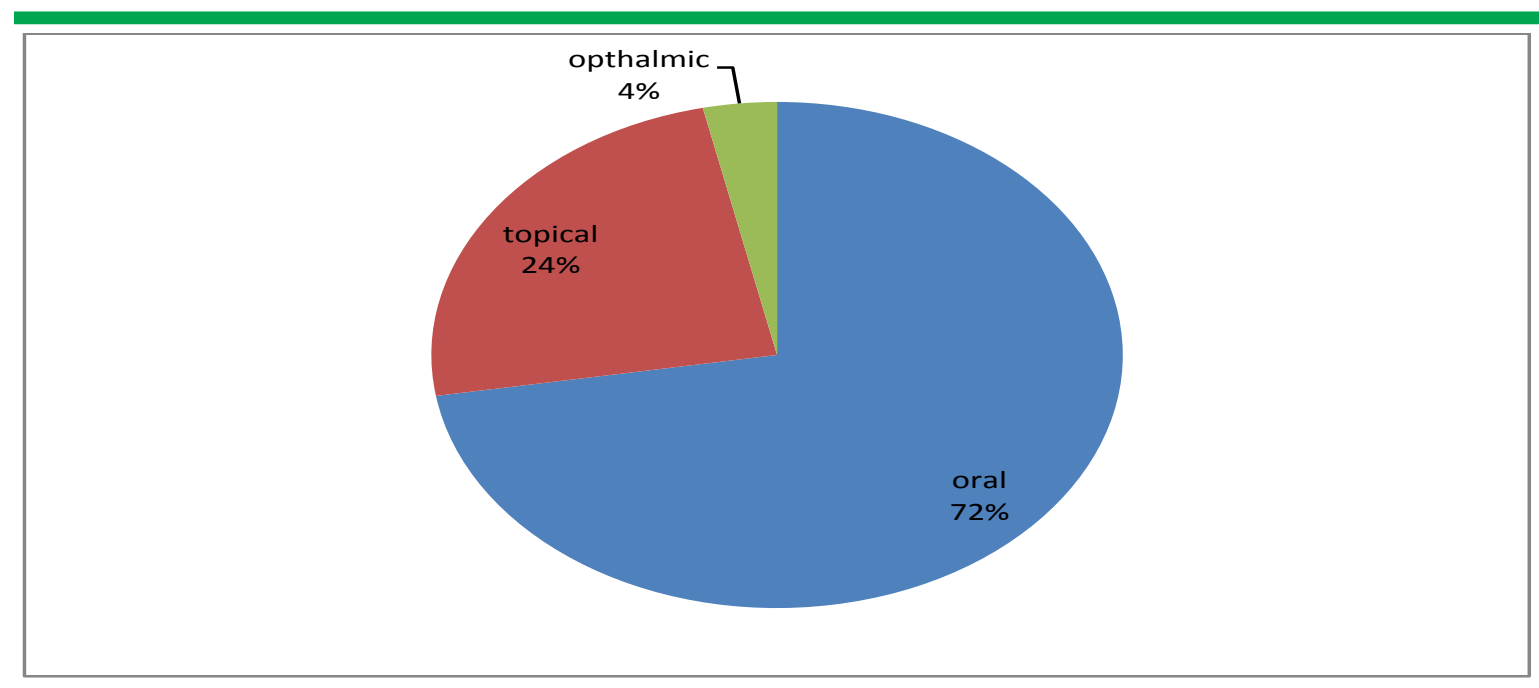

\section{Figure 4: Distribution of crude drug based on route of administration}

Moreover by semi-structured questionnaires through scheduled interviews with the traditional healers, 28 herbal formulations were recorded for 22 common illnesses. The enumerations given below, these common ailments have been arranged along with their botanical sources used against them, their families in bracket, vernacular names such as $\mathrm{N}$ for Nepali, E for English, $\mathrm{R}$ for Rajbanshi, S for Satar; method of preparation including the parts used, dosage and precaution recommended by healers.

\section{Headache}

Botanical source: Allium sativum (Liliaceae); Lasun (N), Garlic (E), Rusni (R) Method of preparation: Bulb of Allium sativum was grounded and mixed with a little bit salt. It was applied locally on forehead till cure. Dosage: It was suggested to take two times a day

Botanical source: Brassica campestris (Cruciferae); Tori (N), Tori (S) Method of preparation: Seeds were grounded and used for massage in head and other affected parts slowly. Dosage: It was suggested to take two to three times a day.

\section{Diabetes}

Botanical sources: (a) Aegle marmelos (Rutaceae); Bel (N) Asare (S), Bel (R) (b) Ocimum sanctum (Labiatae); Tulsi (N) Sacred basil (E), Tulsir (R) (c) Azadirachta indica (Meliaceae); Neem (N), Nimer (R) Method of preparation: One part of i.e. leaves of (a), (b), (c) were grounded and mixed uniformly. Dosage: One tea spoonful was suggested to take per oral twice a day regularly.

\section{High Blood Pressure}

Botanical sources (a) Azadirachta indica (Meliaceae); Neem (N), Nimer (R) (b) Momordica charantia (Cucurbitaceae); Tite karela (N), Bitter gourd (E), Tit karla (R) (c) Swertia chirata (Gentianaceae); Chiraeto (N), Chiraeta (R) Method of preparation: One part of each i.e. leaves of plant (a), fruits of plant (b) were taken and juice was extracted to get filtrate Dosage: One tea 
glass full juice was suggested to take per oral once a day regularly. Precaution: It was not suggested to take for pregnancy and child.

\section{Fever}

Botanical sources: Azadirachata indica (Meliaceae); Neem (N), Nimer (R) Method of preparation: Certain amount (about 4-6 gm) of leaves of Azadirachata indica was crushed and boiled in necessary amount of water. It was then cooled and filtered. Dosage: It was suggested to take per oral twice a day. Precaution: It was not suggested to take for patients of hypertension.

Botanical sources (a) Ocimum sanctum (Labiatae);Tulsi (N), sacred basil (E), Tulsir (R) (b) Zanthoxylum armatum (Rutaceae); Timur (N), Timur (R) (c) Swertia chirata (Gentianaceae), Chiraeto (N), Chiraeta (R) Method of preparation: Equal parts of each, leaves of (a), fruits of (b) and stem-leaves of (c) were boiled in water 5-10 minutes to prepare its decoction. Dosage: it is suggested to take per oral twice to three times a day till cure.

\section{Sore Throat}

Botanical sources (a)Zingiber officinale (Zingiberaceae); Aduwa (N), Ginger (E),Aadi (R) (b) Curcuma longa (Zingiberaceae); Besar (N), Turmeric (E), Besar (R) Method of preparation: The rhizome of (a) was peeled, crushed into small pieces and boiled with water. Powder of rhizomes of (b) was added to it and boiled for 5-10 minutes. Dosage: It was suggested to take two to three times per oral a day till cure. Precaution: It was not suggested to take for patients with gout and joint pain.

Botanical sources: (a) Quercus infectoria (Fagaceae); Majhiphal (N) (b)Terminalia chebula (Combretaceae); Harro (N), Harra (R) (c)Terminalia bellirica (Combretaceae); Barro (N), Barra (R) Method of preparation: Equal parts of fruits' pericarp of $a, b$ and c were dried and crushed to prepare powder. It was mixed with hot water. Dosage: It was suggested to take one full tea glass of mixture twice a day. Precaution: It was not suggested to take for pregnancy and child.

\section{Diarrhoea}

Botanical sources (a) Mangifera indica (Anacardiaceae); Aap (N), mango (E), aam (R) (b) Piper nigrum (Piperaceae); Marich (N), Marich (R) Method of preparation: The bark of (a) was taken and dead tissue are removed. It was crushed to make paste. Fruits of (b) were grounded to fine powder and mixed with the paste of (a). Required amount of water was added to the mixture.Dosage: It was suggested to take per oral two times per day and increase according to condition.

Botanical source: (a) Mangifera indica (Anacardiaceae); Aap (N), Mango (E), Aam (R) (b) Psidium guajava (Myrataceae); Amba (N), Guava (E), Bilati (R) (c) Chuna (lime powder) Method of preparation: The bark of (a) was taken and dead tissues were removed. It was crushed to make paste. Leaves of plant (b) was crushed and to extract juice. It was mixed with the paste of (a). Again very little amount of (c) was added to the mixture. Required amount of water was added to the final mixture. Dosage: It was suggested to take two times per day with required volume of water.

\section{Toothache}


Botanical sources: (a) Zanthoxylum armaturm (Rutaceae); Timur(N), Timur (R) (b) Eugenia caryophyllus (Myrtaceae); Luang (N), Lang (R).Method of preparation: Equal parts of the fruits of (a) and flowering buds of (b) were grounded into powder. Dosage: This preparation was applied to aching portion of tooth. Precaution: It was not suggested to use for children under 5 years of age.

\section{Gastritis}

Botanical sources: (a) Psidium guajava (Myrtaceae); Amba (N), Guava (E), Bilati (R) (b) Trachyspermum ammi (Umbelliferae); Jwano (N) (c) Aloe vera (Liliaceae); Gheeukumari (N), Aloe (E), Gheeukumari (R) Method of preparation: The leaves of plant (a) were crushed to make paste. Fruits of (b) were grounded to prepare powder and mixed with paste of (a). Again juice of (c) was extracted and mixed with above mixture. Dosage: It was suggested to take per oral two teaspoon full mixture with required amount of water.

\section{Allergy}

Botanical source: Artemisia vulgaris (Compositae); Titepati (N), Titpat (R). Method of preparation: The leaves and roots of Artemisia vulgaris was crushed. It was then squeezed to get juice. Dosage: It was suggested to be applied locally on the affected parts till cure. Precaution: After 1-2 hours of juice application, bathing should be done only with clean water not with the use of soap.

\section{Snake Bite}

Botanical source: Moringa oleifera (Moringaceae); Sajina (N), Saijan (R) Method of preparation: Bark of Moringa oleifera was taken and paste was made. The area above the bitten site was tied with cloth. The hair was rubbed on the wound, muttering their enchant (mantra). Dosage: Prepared paste was applied on the wound area.

\section{Burn}

Botanical Source: Aloe vera (Liliaceae); Gheeu Kumari (N). Ghee Kumari (R) Method of preparation: The juice from leaves of Aloe vera was extracted Dosage: It was applied locally on the wounds. and repeated for several times until the pain gets relieved.

\section{Menstrual Disorder}

Botanical source: Corchorus olitorius (Malvaceae); Pata (N); Jute (E); Pata (R). Method of preparation: The leaves of Corchorus capsularis was crushed to get juice. Dosage: It was suggested to take one tea glass of juice once a day per oral till cured.

\section{Jaundice}

Botanical sources: (a) Zingiber officinale (Zingiberaceae); Aduwa (N), Aadi (R). (b) Oroxylum indicum (Bingoniaceae); Totela $(\mathrm{N})$ Method of preparation: The powder of rhizomes of plant (a) and powder of pericarp of (b) were mixed. Dosage: It was taken per oral twice a day till cure.

\section{Dysentery}

Source: Sugar solution (Super saturated) Method of preparation: Certain amount solution of white rusbari and solution of red rusbari were mixed properly and drunk. 
Doasge: It was suggested to take lukewarm solution one tea glass.

\section{Eye Infection}

Botanical source: Centella asiatica (Umbelliferae); Ghodtapre (N). Method of preparation: The leaves of Centella asiatica were collected and washed with clean water. It was then crushed to obtain juice. Dosage: It was suggested to apply two drops of juice twice a day in the infected eye. Precaution: It was suggested to stop the taking if any side effect was seen.

\section{Piles}

Botanical source: Coriandrum sativum (Umbelliferae); Dhaniya (N) Method of preparation: The fruits of Coriandrum sativum were soaked with water for 12 hours. Dosage: It was suggested to drink twice a day till cure.

\section{Kidney stone}

Botanical source: Macrotyloma uniflorum (Leguminosae); Gahat (N), Kurthi (S) Method of preparation: The seeds of the plant were boiled with water for half an hour. It was cooled upto lukewarm. Dosage: It was suggested to drink 1/2-1liter of the preparation twice a day till cure.

\section{Wounds in Mouth}

Botanical source: Citrus limon (Rutaceae); Kagati (N), Lemon (E) Method of preparation: The bark of Citrus lemon was peeled, dried and grounded to make powder. Dosage: It was suggested to take per oral one teaspoon full powder with required amount of water till cured.

Botanical source: Emblica officinalis (Euphorbiaceae); Amla (N), Amla (R).Method of preparation: The pericarp of Emblica officinalis was cut into small pieces and dried. Dosage: It was suggested to take 2-3 of dry fruits twice a day till cured.

\section{Asthma}

Botanical source: Zingiber officinale (Zingiberaceae); Aduwa (N), Aadh (R). Method of preparation: The rhizome of plant Zingiber officinale was washed and crushed into small pieces. It was dried and grounded to make powder. Dosage: It was suggested to take one teaspoonful powder mixed with honey and required amount of hot water twice a day.

Botanical source: (a) Mimosa pudica (Leguminosae); Lajjawatijhar (N), Chamki (R). (b) Piper nigrum (Piperaceae), Marich (N), Marich (R) Method of preparation: The roots of plant (a) were taken, washed and grinded to make paste. The fruits of (b) were grounded to make powder and mixed with previously prepared paste of root's plant (a). Dosage: It was suggested to take a teaspoonful paste with some amount of hot water.

\section{Swelling and Inflammation}

Botanical source: Calotropis gigantea (Asclepiadaceae); Aakh(N). Method of preparation: The latex was collected from leaves and stem. Dosage: It was suggested to apply locally two times a day in the affected area till cured.

\section{Constipation}

Botanical source: (a) Terminalia chebula (Combretaceae); Harro (N), Harra(R) (b) Terminalia bellirica (Combretaceae); Barro (N), Barra (R). (c) Emblica officinalis (Euphorbiaceae); 
Amala(N), Amla (R). Method of preparation: The dry fruits of $a, b$ and $c$ were grounded to fine powder and mixed them in equal proportion. Dosage: It was suggested to take per oral one teaspoonful powder, twice a day for 15 days.

\section{Pneumonia}

Botanical source: (a) Cynodon dactylon (Graminae); Dubho (N). Duib (S) (b.) Psidium guajava (Myrtaceae), Amba (N), Amrudh (S) (c.) Zingiber officinale (Zingiberaceae); (Aduwa) Aadi (S)

Method of preparation: Aerial parts of plant (a) and leaves of plant (b) were cut into small pieces and grounded to make paste. The paste was mixed with the juice obtained from the rhizomes of plant (c). Dosage: It was suggested to take per oral one tea spoonful twice a day. In Rajbanshi and Satar community, spiritual based five healing techniques, Phukphak, Tantrik Puja, Bali, Jantar-mantar and kul bigreko, that are similar with the findings of Prem Kumar Khattry ${ }^{1}$ but they are not practicing dhami ritual in both tribes. A large number of crude drugs reported to have medicinal value in this study was also supported by the findings of other researchers but certain result had not been reported yet from other researchers. For example, the aerial parts of plant Cynodon dactylon and leaves of Psidium guajava was reported for pneumonia in the present study but Kurmi et al, ${ }^{19}$ Manandhar ${ }^{17}$ and Medicinal plant of Nepal (2007), a bulletin from Department of Medicinal Plants, $\mathrm{Nepal}^{18}$ reported its use in diarrhoea and checks bleeding from nose, cut and wounds. In present study we first time found the use of roots of Mimosa pudica for asthma, Leaves of Corchorus olitorius for menstrual disorder, Moringa oleifera for snake bite and bark of Magnifera indica for diarrhoea.

A total of 28 traditional formulations were prepared from the 41 medicinal plant species identified in this study. The majority of formulations were prepared as paste or juice. Crushing, pounding, and grinding are executed using a pestle in a mortar made of hard stone. Most people who participated in interviews and group discussions were familiar with the species used to deal with common ailments like cough and cold, digestive problems, fever, headache, skin infection, and in such cases plant based medicinal remedies were used on a regular basis. For complex problems like chest pain, menstrual disorders, rheumatism, or eye and kidney problems, people took advice from local traditional healers. Traditional healers believe in a form of sanctity of the curative power of medicinal plants. They thus keep secrecy over remedy formulation, believing that the medicines would lose their potency if known to other people. Dangol et al ${ }^{10}$ found that a total of 71 plants were identified to be of medicinal use to the Darai. The plants were used to treat a range of diseases including headache, diarrhea, and problems associated with menstruation and pregnancy. Most of the plants were commonly used by all groups of Tharus ${ }^{21}$. Singh et al found that out of 66 medicinal plants recorded from study area, highest number of plants belongs to herb (53\%) followed by tree, shrubs and climber. As for as availability of medicinal plants is concerned 39\% medicinal plants are cultivated for food, fruit, spices and trade; thus are easily available for medicinal purposes ${ }^{20}$.

\section{CONCLUSION}

Traditional healers in Rajbanshi and Satar community were aged between 50 to 70 years. Spiritual based five healing techniques and/or approaches used by traditional healers were 
Phukphak, Tantrik Puja, Bali, Jantar-mantar and kul bigreko. A total of 28 medicinal formulations were prepared from the 56 medicinal plants identified in this study. Preparation methods included paste, juice, decoction, infusion and chewing the raw plant. In present study we first time found the use of roots of Mimosa pudica for asthma, leaves of Corchorus olitorius for menstrual disorder, Moringa oleifera for snake bite and bark of Magnifera indica for diarrhoea. If these crude drugs are supported by phytochemical and Pharmacological screening, they may be significant to lead the discovery of drugs that may contribute for the income generation of the local people and contribute to the national economy. Rajbanshi and Star are conscious about their identity, natural resources, sustainability and public services. Their traditional life is simple with rich cultural heritage. They have sound traditional techniques and skill to serve the people of their locality. Traditional healers may prop up the national health care system by their service if they were supported by the scientific trainings and approach to integrate with modern health care system.

\section{RECOMMENDATION}

Nepal is rich in traditional healing practice. Government has to identify the strength of those traditional healers and try to integrate them with modern health care system as majority of the people still relay on them and access of modern medicines to the villagers is still poor. Furthermore there is possibility of search of new drug candidate from the identified herbal resources.

\section{ACKNOWLEDGEMENT}

We are indebted to all those traditional healers of Rajbanshi and Satar community, without whose help, this work would not been a reality. We are also thankful to Mr. Kriti Raj Ojha, lab mate of Manmohan Memorial Institute of Health Sciences, Soalteemod, Kathmandu, who helped to prepare the herbarium specimen and crude drug samples in the Pharmacognosy Laboratory.

\section{REFERENCES}

1. Khattry PK. The Nepalese Traditional Concept of Illness and Treatment. DADA Rivista di Anthropologia post-globale. 2013; 45-54. Available from:www.dadarivista.com> 2011- dicembre

2. Raut B. and Khanal DP. Present status of Traditional Healing Healthcare System In Nepal. International Journal of Research in Ayurveda and Pharmacy, 2011;2 (3): 876882

3. Raut B. Traditional phytotherapy of crude drugs practiced by the street healers of Pokhara valley, Nepal, Journal of Nepal Pharmaceutical Association. 2010;XXVI (1):916

4. Bhattachan KB. Country Technical notes on Indigenous People's Issue-Feredral Demographic Repubic of Nepal, International fund for Agriculture Development and Asia Indigenous pact, 2012; http/www.ifad.org/documents/38714170/40224860/Nepal_ctn.pdf/ 
5. Yadav U, Hugo A, Boon EK, Yadav S, Shrestha KK. Indigenous use and bio-efficacy of medicinal plants in the Rasuwa District, Central Nepal. Journal of Ethnobiology and $\begin{array}{llcll}\text { Ethnomedicine } & 2010 ; & 6 & \text { (3):1-10 } & \text { Available }\end{array}$ from:http://www.ethnobiomed.com/content/6/1/3

6. Rijal A. Surviving on Knowledge: Ethnobotany of Chepang community from Mid-hills of Nepal, Ethnobotany Research and Application. 2011; 9:181-215. Available from:www.ethnobotanyjournal.org/vol9/1547-3465-09-181.pdf

7. Acharya R. Ethnobotanical study of medicinal plants of Resunga hill used by Magar community of Badagaun VDC, Gulmi district Nepal, Scientific Word 2012;(10 ): 54-65

8. Bhatta LR. Ethnobotanical study in a village at Rukum District, Nepal, Banko Jankari. 1999;9(2):40-43

9. Tamang G. An Ethnobotanical study of the Tamang People, Our Nature, 2003;1:37-41

10. Dangol DR and Gurung SB. Ethnobotanical Study of Darai Tribe in Chitwan District, Nepal. In Proceeding of Third National Conference on Science and Technology, Vol. II, Royal Nepal Academy of Science and Technology (RONAST), Kathmandu, Nepal, March 8-11, 1999; 1194-1213.

11. Dahal M and Das BD. Ethnobotany of Aathpahariya Rai in and around Dhankuta Bazar. In Proceeding of Third National Conference on Science and Technology, Vol. II, Royal Nepal Academy of Science and Technology (RONAST), Kathmandu, Nepal, March 8-11,1999; 1351-1358.

12. Yadav RKP. Medicinal Plants and Traditional Medicinal Practice in Eastern Part of Parsa District, Nepal. In Proceeding of Third National Conference on Science and Technology, Vol. II, Royal Nepal Academy of Science and Technology (RONAST), Kathmandu, Nepal. March 8-11, 1999; 1421-1426.

13. Manandhar NP. Ethnobotanical notes on certain medicinal plants used by Tharus of Dang-Deukhuri district, Nepal. Int. J. Crude Drug Res.1991;23 (4):153-159.

14. Trease GE and Evans WC, Pharmacognosy. UK: SAUNDERS Publication; 2002

15. Wallis TE. Textbook of Pharmacognosy, 15th edition. New Delhi, India: CBS Publishers and distributors, 2002

16. Rajbhandari TK, Joshi NR, Shrestha T, Joshi SKG and Acharya B. Medicinal plants of Nepal for Ayurvedic drugs, Govt. of Nepal, Ministry of Forest and Soil Conservation, Department of Plant Resources, Natural Products Development Division, Thapathali, Kathamandu, Nepal; 1995

17. Manandhar NP, Plants and People of Nepal. USA: Timber Press; 2002

18. Department of Plant Resources, Medicinal Plants of Nepal. Bulletin No. 3. Kathmandu, Nepal. 1997

19. Kurmi PP and Kattel LP, A study on plants used by traditional healers (Road) in Midwestern and Eastern region of Nepal. Plant Resources. 2004;16-21 


\section{Original Article}

20. Singh AG, Kumar A and Tewari DD, An ethnobotanical survey of medicinal plants used in Terai forest of western Nepal. J Ethnobiol Ethnomed, 2012; 8(1) 1-14.

21. Dangol DR and Gurung SB, Ethnobotany of the Tharu Tribe of Chitwan District, Nepal. International Journal of Pharmacognosy, 1991; 29(3) 203-209. 